\title{
La pantalla videoescénica: interfaz entre presencia y huella
}

\section{Pantaila bideoeszenikoa: presentziaren eta aztarnaren arteko interfazea The videoscene screen: interface between presence and trace}

\author{
Gustavo Montes Rodríguez ${ }^{\star}$ \\ Universidad Rey Juan Carlos-URJC
}

RESUMEN: Esta investigación tiene como objetivo determinar las relaciones que se establecen entre presencia e imagen audiovisual en la construcción de un producto híbrido, la obra videoescénica. El diseño metodológico parte de planteamientos de la fenomenología audiovisual de André Bazin y de la teoría del teatro para establecer posteriormente una clasificación técnica de la imagen videoescénica. Se llega a la conclusión de que la pantalla funciona como interfaz que establece la unidad de sentido entre cuerpo del actor y su imagen especular y posibilita la expansión figurativa de personajes, acciones, espacio y tiempo basada en la fragmentación y la flexibilidad de la imagen audiovisual.

PALABRAS CLAVE: Videoescena; personaje; hibridación; pantalla; presencia; huella.

ABSTRACT: This research aims to determine the relationships that are established between presence and audiovisual image in the construction of a hybrid product, the videoscene play. The methodological design is based on approaches from André Bazin's audiovisual phenomenology and from theater theory to later establish a technical classification of the videoscene image. It is concluded that the screen functions as an interface that establishes the unity of meaning between the actor's body and his mirror image and enables the figurative expansion of characters, actions, space and time based on the fragmentation and flexibility of the audiovisual image.

KEYWORDS: Videoscene; character; hybridization; screen; presence; trace.

\footnotetext{
* Correspondencia a / Corresponding author: Gustavo Montes Rodríguez. Facultad de Ciencias de la Comunicación. Despacho 243-Edificio Departamental I. Universidad Rey Juan Carlos. Campus de Fuenlabrada. C/ Camino del Molino, s/n (28943 Fuenlabrada-Madrid) - gustavo. montes@urjc.es - https://orcid.org/0000-0003-1811-0737

Cómo citar / How to cite: Montes Rodríguez, Gustavo (2021). "La pantalla videoescénica: interfaz entre presencia y huella», Zer, 26(51), 99-120. (https://doi.org/10.1387/zer.22533).

Recibido: 10 febrero, 2021; aceptado: 17 septiembre, 2021

ISSN 1137-1102 - eISSN 1989-631X / (c) 2021 UPV/EHU

(c) (i) () $\ominus$ Esta obra está bajo una Licencia

(c) Creative Commons Atribución-NoComercial-SinDerivadas 4.0 Internacional
} 


\section{Introducción}

Desde su utilización por Erwin Piscator, que introdujo en 1928 proyección cinematográfica en la puesta en escena de Las aventuras del bravo soldado Schweik (Morales Astola, 2003), la pantalla ha formado parte de ese abanico de posibilidades del que dispone el director de escena para establecer la escenificación. La aparición y posterior popularización del vídeo en los años ochenta, más manejable y asequible económicamente, la convirtió en un recurso de frecuente utilización en espectáculos teatrales, incluso de mediano y pequeño formato. Esta profusión de pantallas no ha ido acompañada por una sistematización de su uso, como pone de manifiesto Jaume Melendres (2005) cuando destaca que los directores desconocen en muchos casos los efectos que se derivan de su aparición en el escenario en interrelación con los elementos específicamente teatrales. Por su parte, la bibliografia académica tradicional sólo ha abordado el fenómeno de una forma tangencial, reduciéndolo a un recurso expresivo de origen lumínico o a una forma moderna de resolver la escenografia. No obstante, desde la primera década del siglo XXI, la necesidad de un acercamiento riguroso a dichos efectos ha sido destacada por diversos investigadores, como el argentino Luis Thenon (2005), el francés Ludovic Fouquet (2006) o los españoles Alicia E. Blas Brunel (2001), Morales Astola (2003), el propio Melendres (2005), Paz Gago (2006), Iglesia Simón (2008) e Isabel de Naverán (2010), que, sin embargo, no ha llegado a culminar en una verdadera poética cognoscitiva y constructiva.

El presente artículo se inserta en una línea de investigación que pretende aportar fundamentos teóricos y constructivos que profundicen en el conocimiento de la obra videoescénica. Tiene como objetivo determinar las relaciones que, a través de la pantalla o cualquier otro soporte de proyección, se producen entre el personaje teatral, presencia efectiva del actor en el escenario, y la imagen de personajes, objetos y espacios proyectados para constituir unidades de sentido. La investigación señala, por tanto, a la pantalla de proyección como interfaz entre presencia e imagen audiovisual, es decir, entre dos modos de representación, el dramático y el narrativo de enunciación audiovisual.

Para llevar a cabo su propósito, se ha elaborado un diseño metodológico que parte de presupuestos de la teoría audiovisual, basados en la orientación fenomenológica de André Bazin (2006) para explicar la naturaleza de la imagen audiovisual, y en los presupuestos semióticos de Christian Metz (2002) para dar cuenta de la imagen como signo, junto a aportaciones de la teoría teatral, particularmente aquellas establecidas por José Luis García Barrientos (2001) en su modelo de análisis dramatológico, que sustentan una clasificación técnica de la imagen videoescénica. El diseño metodológico justifica una estructura en tres partes. La primera da cuenta de la naturaleza de la imagen audiovisual y su vinculación con los elementos escénicos a través de la conjunción de huella (la imagen de objetos y personajes registrados y proyectados audiovisualmente) y presencia (los objetos y personajes presentes efectivamente 
en la escena). La segunda aborda el concepto de interfaz entorno a las relaciones que se producen a través de la pantalla entre personaje audiovisual y personaje escénico y su intervención en las configuraciones y agrupamientos de personajes. Finalmente, el tercer apartado, que justifica su mayor extensión por sus aportaciones técnicas, establece las funciones de la pantalla a través de diferentes categorías que sistematizan las consecuencias de su aparición en la obra videoescénica.

\section{Presencia y huella}

La oposición que en un primer momento se establece entre personaje teatral e imagen audiovisual queda patente desde el concepto de aura de Walter Benjamin, «el aquí y ahora de la obra de arte, su existencia irrepetible en el lugar en el que se encuentra» (Benjamin, 1989: 22). El actor de teatro presenta en persona al público su ejecución artística. Por el contrario, el actor de cine presenta su actuación a través de lo que Benjamin denomina un mecanismo, que tiene dos consecuencias. En primer lugar, la cámara realiza planos desde distintas posiciones y registra fragmentos que serán ensamblados a través de la técnica del montaje, puesto que el mecanismo no está obligado a respetar la totalidad de la actuación. En segundo lugar, el actor cinematográfico, puesto que no es él mismo quien presenta su actuación a los espectadores, no podrá nunca acomodar su trabajo al público, posibilidad reservada al teatro. El espectador cinematográfico, por tanto, se compenetrará con el actor sólo en tanto que se compenetra con el aparato: "Al cine le importa menos que el actor represente ante el público un personaje; lo que le importa es que se represente a sí mismo ante el mecanismo» (Benjamin, 1989:35).

Relacionada con el aura de Benjamin (1989), la noción de presencia aparece como un elemento definitorio del personaje teatral frente al personaje audiovisual y, por extensión, entre el modo teatral y el modo narrativo de enunciación audiovisual. Comúnmente se acepta que el teatro admite todas las ilusiones excepto la de la presencia. El actor se nos puede aparecer bajo cualquier disfraz, pero está allí, frente a los espectadores, compartiendo el instante. El cine, en cambio, puede sustituir todas las realidades menos la de la presencia física del actor. A esta conclusión se llegaría aplicando los postulados sobre el aura de Benjamin y que, de producirse efectivamente, dificultaría la relación entre presencia e imagen audiovisual. Sin embargo, la teoría de Bazin, que parte del supuesto de que puede concebirse una posición intermedia entre presencia y ausencia, viene a despejar el camino:

Resulta falso decir que la pantalla sea absolutamente impotente para ponernos en presencia del actor. Lo hace a la manera de un espejo (del que hay que admitir que repite la presencia de lo que refleja), pero de un espejo de reflejo diferido, cuyo azogue retuviera la imagen. (...) Lo que perdemos de testimonio directo ¿no lo ganamos gracias a la proximidad artificial que per- 
mite el acercamiento de la cámara? Todo sucede como si en el parámetro Tiempo-Espacio, que define la presencia, el cine no nos devuelva más que una duración debilitada, disminuida, pero no reducida a cero, mientras que la multiplicación del factor espacial restablecería el equilibrio de la ecuación psicológica. (Bazin, 2006: 174)

Para Bazin «la huella de lo real es, en cierto modo, lo real» (Esqueda Verano, 2019: 8), ya que en el cine, y por extensión en el audiovisual, se produce un "proceso de transferencia del objeto a la imagen» (Esqueda Verano, 2019: 9), un reconocimiento perceptivo por parte del espectador que es característico de la imagen de registro. Planteado de esta manera, la relación entre presencia y huella parece resuelto, puesto que el audiovisual dispone de procedimientos de puesta en escena y puesta en serie que pueden favorecer la pasividad o, por el contrario, excitar la conciencia del público, y el teatro cuenta con los suyos para intentar atenuar la oposición psicológica entre el espectador y el héroe. El audiovisual y el teatro no se encontrarían tan alejados expresivamente uno del otro, ya que tenderían a provocar dos actitudes receptivas sobre las cuales el director posee un amplio control. Este control se lleva a cabo en la obra videoescénica en el proceso de escenificación, señalado como el momento en el que se efectúan las decisiones tomadas en cuanto a la integración de los elementos procedentes del audiovisual en el espectáculo teatral. La importancia del director de escena cobra un valor mayor si tenemos en cuenta que, en la actualidad, la tecnología digital permite la creación de personajes y escenarios que cuestionan el concepto tradicional de la imagen registrada, huella del mundo referencial. En esto insiste Mitchell cuando afirma que «si el aura significa recuperar la vitalidad del original, literalmente el aliento de vida del original, entonces la copia digital puede acercarse más a parecerse o a sonar como el original que el original mismo» (Mitchell, 2020: 397). La sustitución del negativo y el registro analógico por el disco informático ha creado cierta crisis en la hipotética verdad de las imágenes, privándolas del referente, convirtiéndolas en datos informáticos capaces de ser manipulados en el proceso de postproducción. "Es como si la huella del mundo físico — sostiene Àngel Quintana (2011: 45) — no tuviera legitimidad en el mundo de los píxeles informáticos y que fuera preciso volver a la creación de imágenes sin huella».

De hecho, en muchas escenificaciones se proyectan espacios generados por ordenador en relación directa con escenarios registrados de la realidad que conviven con el escenario teatral y se sustentan en la relación entre la presencia del actor que encarna al personaje teatral, dotado de esa doble aura, la real y la ficticia del personaje, con personajes y espacios construidos a base de píxeles, sin más relación con lo real que ser la quimera de su creador, y proyectados en escena. Y todo ello resultaría coherente, puesto que la clave interpretativa no viene determinada por cuestiones ontológicas ni por la búsqueda de la verdad, sino por las convenciones representativas que se ha impuesto en cada período de la historia de la cultura (Auerbach, 1993). 
La pérdida del testimonio directo del teatro se gana gracias a la proximidad artificial que permite el acercamiento de la cámara o el mecanismo de postproducción utilizado. La multiplicación del elemento espacial que permite el audiovisual restablecería el equilibrio de la ecuación entre la conciencia individual activa del espectador teatral y la adhesión pasiva propia de la proyección audiovisual, como advierte Bazin (2006) respecto al cinematógrafo. En la obra videoescénica es la presencia del actor en relación con el espacio escénico y el espacio audiovisual proyectado en la pantalla, inserta en la escenografia, lo que le confiere unidad, lo que vincula sintácticamente presencia y ausencia. Si bien los espacios reflejados en la pantalla muestran fragmentos de espacios audiovisuales, el espectador percibe e interpreta en relación con la actividad del personaje teatral en el espacio escénico. Se podría decir que las imágenes toman el aura a través de esa relación y que los espacios audiovisuales, que fueron registrados antes, se interpretan desde el aquí y ahora del hecho teatral.

La relación no es unidireccional, sin embargo, puesto que el espacio audiovisual deja también su impronta en la representación teatral: su estructura espacial tiende a la multiplicidad, si no a la fragmentación, propia del audiovisual, debido a que la pantalla puede mostrar todos los espacios que se consideren. Esta posibilidad también afecta al grado de representación del espacio: todo espacio latente es susceptible de ser situado a la vista del espectador en la pantalla, desde una tormenta a un choque de trenes, desde el lugar de trabajo de un personaje a su desplazamiento en el metro. Pero no sólo esto, sino que puede ser presentado a través de los ojos de cualquiera de los personajes, fragmentando también la mirada del espectador, facilitando su identificación con tal o cual personaje en cualquier momento a través de determinados factores que intervienen en la enunciación audiovisual, como la focalización perceptiva u ocularización interna múltiple o variable (Gaudreault y Jost, 2001).

Sin embargo, Jaume Melendres (2005) advierte del poder de la imagen cuando es confrontada con los elementos teatrales. Lo audiovisual, dice, siempre prevalecerá sobre la representación teatral, puesto que la imagen «produce menos vértigo, tal y como lo demuestran en cada vuelo trasatlántico los pasajeros que atraviesan los océanos y están más atentos a la película que ponen en pantalla que al diálogo directo de las nubes en su azarosa y turgente copulación» (Melendres, 2005: 67). Sin entrar a valorar lo afortunado de la metáfora, sí conviene rebatir algunos aspectos. Primero, el «diálogo» de las nubes no forma parte del mismo texto que la película que se está emitiendo (en todo caso, serían dos textos diferentes sobre los cuales se debe optar); y, segundo, esa "copulación», además de «turgente», es «azarosa», y esto es lo relevante, puesto que señala que no es una verdadera acción que se inserte en el desarrollo lógico de una historia. Por tanto, no despertará el interés del espectador más allá de la visión atmosférica o estética del fenómeno. Inserta en la lógica de la obra videoescénica, la imagen audiovisual se torna videoescénica, esto es, se relaciona con los demás elementos teatrales para constituir unidades de sentido. Cada elemento de la escena, audiovisual o de naturaleza teatral, no remitirá a un referente externo, sino 
que halla su significación en relación con otros elementos de la misma. Nos remite, por tanto, a la misma historia, contada a través de la obligada relación de dos modos de representación que conforman un único texto.

\section{La noción de interfaz videoescénico}

El mundo posible que presenta la obra videoescénica, que vincula presencia e imagen, le ofrece al espectador una puerta de entrada: la pantalla. A través de ella, la forma de la expresión audiovisual se inserta en la forma de la expresión teatral, facilitando la interpretación de los contenidos al espectador, que dispone de la capacidad necesaria para comprender la interrelación entre ambos mundos, puesto que vive inmerso en una cultura universal de la imagen (Fouquet, 2006), esto es, dispone de la competencia para comprender ese mundo híbrido - el mundo videoescénico- que le ofrece el escenario.

La pantalla, pues, se nos muestra como interfaz entre dos mundos reflejados a través de dos modos de representación. Desde la informática se entiende la interfaz como la conexión fisica y funcional entre dos sistemas o dispositivos de cualquier tipo que permite la comunicación entre distintos niveles. Esta investigación entiende la pantalla como interfaz espacial, como el lugar donde se produce la interacción, el espacio donde se desarrollan los intercambios entre el hombre y el objeto (Scolari, 2004). En la obra videoescénica, entre el actor escénico que encarna al personaje (el hombre) y la pantalla, vehículo de contenido audiovisual (el objeto). A través de la pantalla el personaje teatral adquiere la facultad de comunicarse con un mundo que ya ha ocurrido, que ha sido registrado en otro tiempo y en otro lugar, pero que al mostrase en su presencia, se torna lo suficientemente cercano como para establecer entre ellos un proceso comunicativo del que el espectador extraerá un sentido unitario. El personaje teatral ve ampliado de este modo su mundo, antes restringido a aquello que está efectivamente en el escenario o a su construcción imaginaria a través de la verbalidad, la gestualidad o el movimiento. Es la pantalla, como soporte fisico de proyección, la que le permite el acceso.

\subsection{El personaje Videoescénico}

Si el personaje dramático se define como «la encarnación del personaje ficticio en la persona escénica, esto es, un actor representando un papel» (García Barrientos, 2001: 155), el personaje del drama videoescénico se concibe como el personaje ficticio encarnado en la persona videoescénica, un actor que representa un papel en la escena y que también es doblado a través de la tecnología digital, adquiriendo la capacidad de relacionarse, indistintamente, con otros personajes, a su vez presentes en la escena y/o registrados audiovisualmente. La persona diegética es encarnada por el 
actor, tanto en el escenario como en el registro audiovisual, dando lugar a un personaje representado teatral y audiovisualmente: el personaje videoescénico. La ecuación PERSONAJE DRAMÁTICO = PERSONAJE FICTICIO + ACTOR, que establece García Barrientos (2001), resulta válida también si se sustituye el término PERSONAJE DRAMÁTICO por el de PERSONAJE VIDEOESCÉNCIO. Ambos coinciden en la forma de contenido, sin embargo, no en la forma de la expresión, puesto que el personaje videoescénico se sustenta no sólo a través del modo de representación teatral, sino también a través del modo de representación narrativo de enunciación audiovisual. El actor que desarrolla su tarea en la obra videoescénica se verá abocado a desdoblarse en escena y en pantalla, a relacionarse con otros actores que encarnan personajes que sólo aparecen en la proyección o con el registro audiovisual de espacios y objetos.

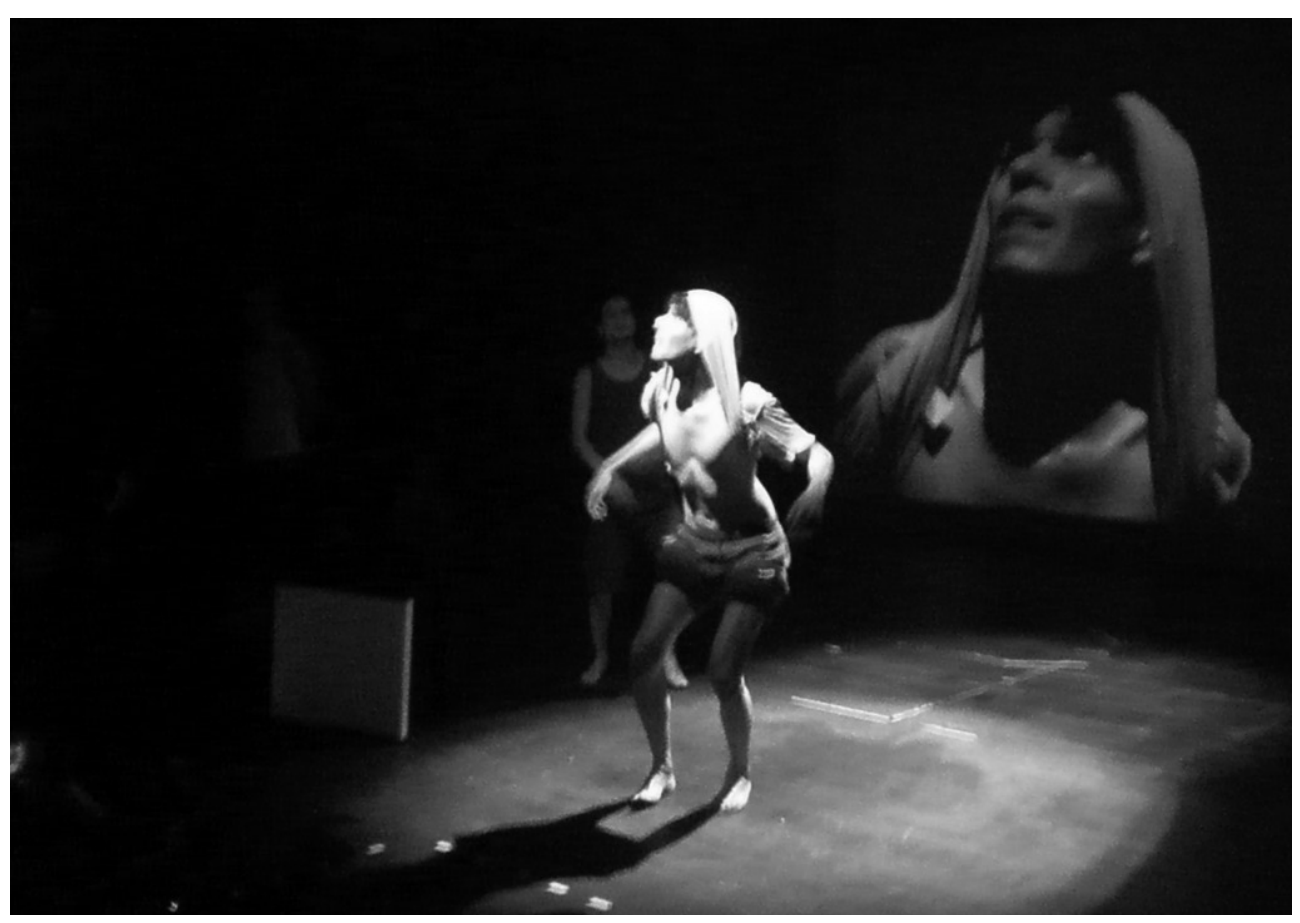

IMAGEN 1

Desdoblamiento de personaje escénico en personaje audiovisual ${ }^{1}$. Nosotros, hijos de la guerra de Simbiontes.

Sala Cuarta Pared, 2011. Cortesía de la compañía

1 En esta escena el personaje entra en relación con su imagen al mismo tiempo en el que se desarrolla la acción escénica. En este caso a través de un diálogo no verbal basado en sonidos guturales y gestualidad, que se justifica en la tortura a la que está siendo sometido el personaje. 
En este producto híbrido el actor puede llegar incluso a establecer diálogos con su doble ficticio registrado audiovisualmente o con el doble ficticio de otro personaje, como ocurre en Nosotros, hijos de la guerra (2011) de la compañía Simbiontes (imagen 1). De este modo se incide en el carácter artificial del personaje representado, puesto que la actuación del actor no puede producir imágenes verdaderas más que utilizando medios totalmente contrarios a su naturaleza. El trabajo del actor se fundamenta, utilizando el título de la célebre obra de Diderot (1995), en una paradoja. Se trata de asumir una operación que se sabe fraudulenta para «hacer nacer lo verdadero a partir de lo falso y hacer creíble la mentira» (Abirached, 1994: 73). La paradoja se acrecienta en la obra videoescénica, puesto que la presencia física del actor ya no es continua, al ser sustituido en determinados momentos de la acción por su reproducción audiovisual o, incluso, por su doble virtual, generado a través de procedimientos informáticos. La tecnología permite la aparición "de un cuerpo renovado, fantasmado distintamente», donde otro cuerpo nace «de la espuma de los números» (Pavis, 2000: 60). El actor, por tanto, da cuenta de esa doble condición de presencia y huella que caracteriza al personaje videoescénico.

\subsection{Aspectos De LA CONFIGURACIÓN VIDEOESCÉNICA}

En las distintas escenas que componen un drama se producen agrupaciones de personajes que dan cuenta del desarrollo de la acción, además de influir, a través de las relaciones que se producen entre ellos, en la caracterización de los mismos. Estas agrupaciones de personajes en una escena componen una configuración, definida como la aparición un conjunto parcial de personajes en un determinado momento del drama, entendiéndose que cada escena tiene una configuración diferente (Spang, 1991). El reparto quedaría definido como el resultado de sumar todas las configuraciones propuestas, esto es, el conjunto de personajes que aparecen en el drama. Tanto las diferentes configuraciones como el reparto no deben entenderse como una mera acumulación de personajes (García Barrientos, 2001), sino como estructuras en las que se relacionan los personajes, parcial en las primeras, total en el segundo, bajo diferentes jerarquías y diferentes grados y niveles de importancia. 


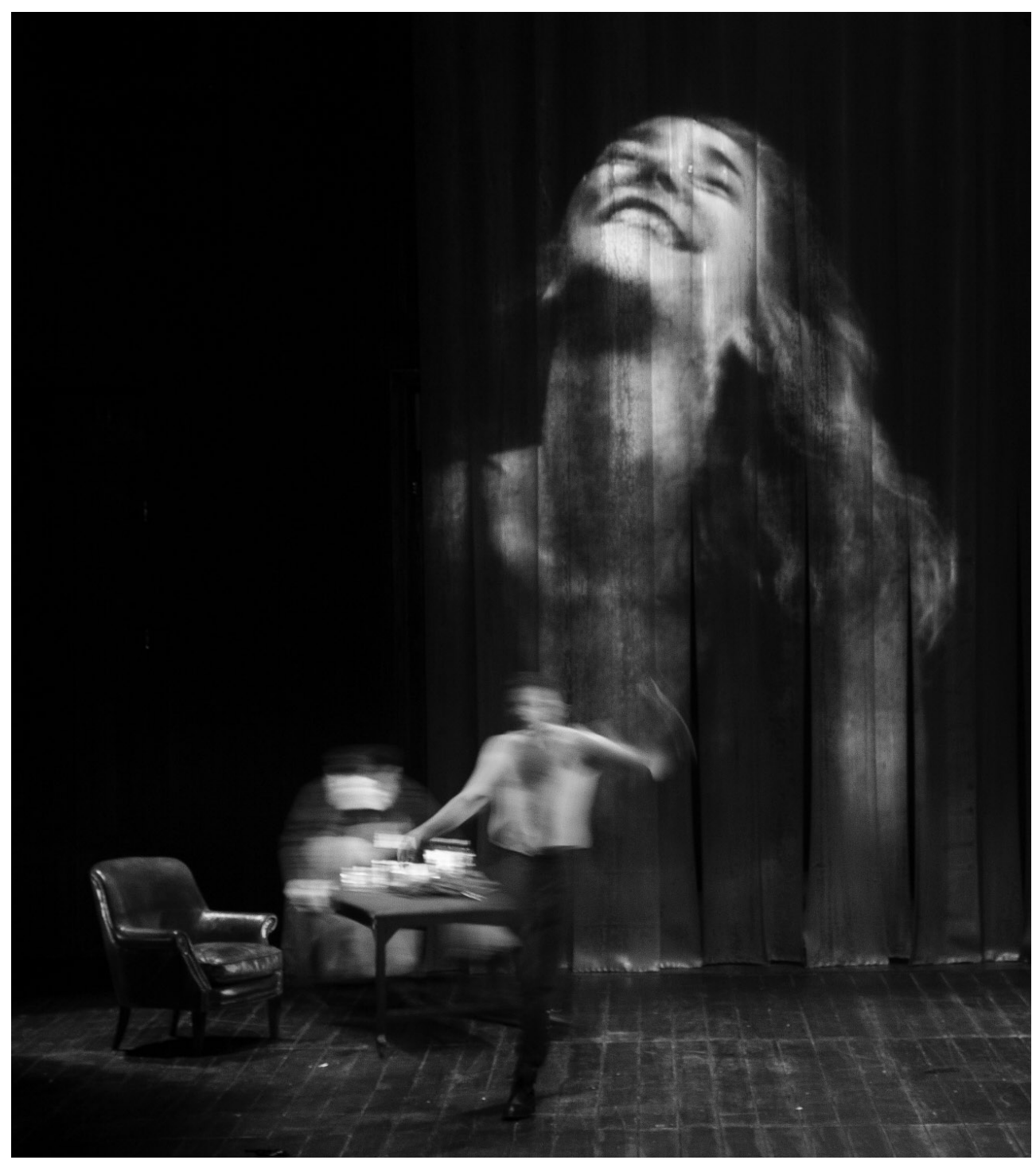

IMAGEN 2

Interacción entre personaje escénico y audiovisual ${ }^{2}$. Los hermanos Karamazov, dirigida por Gerardo Vera. Centro Dramático Nacional, 2012. Cortesía de Álvaro Luna

2 En esta escena se produce una agrupación de tres personajes, dos escénicos y uno videoescénico. Éste es representado audiovisualmente y ha sido registrado en otro tiempo y otro lugar, pero establece una interacción dialógica con uno de los personajes escénicos. 
En la obra videoescénica tanto el reparto, la configuración y la interacción adquieren condiciones específicas derivadas de la aparición de la enunciación audiovisual. El reparto estará formado por personajes escénicos que son doblados por su imagen audiovisual y por personajes que sólo son representados audiovisualmente (imagen 2). Dependiendo de su participación en la acción, los personajes audiovisuales formarán parte de la lista de dramatis personae o quedarán relegados a la consideración de ambientes (Casetti y Di Chio, 1996), como sucede en un relato cinematográfico. Las configuraciones de las distintas escenas se verán afectadas cuantitativa, temporal y cualitativamente por la irrupción del personaje audiovisual. En el aspecto cuantitativo el número de personajes es susceptible de aumentar, puesto que las restricciones habituales a las que se enfrenta el director de escena respecto al tamaño de la sala teatral o al número de componentes de la compañía, son aminoradas por la posible proyección ilimitada de personajes, doblados de la escena o sólo registrados audiovisualmente. En una eventual puesta videoescénica de La Casa de Bernarda Alba, las doscientas mujeres de luto que acuden al duelo del marido de Bernarda, que Kurt Spang señala como «una exageración lorquiana» (Spang, 1991: 177), podrían ser efectivamente representadas a través del audiovisual y abandonarían su condición de ambiente si se produce una relación del personaje dramático con algunas de ellas.

A diferencia del audiovisual, en el que se puede dar un reparto multitudinario si así lo exige el realismo mimético de la historia, en el teatro se tiende a una manifiesta concentración de personajes. La capacidad de la imagen audiovisual para registrar cualquier elemento, desde el más pequeño objeto a un majestuoso espacio o la acción de cualquier personaje, no conoce más límite que la mente creadora del autor quiera imponerle. En el audiovisual todo es susceptible de ser representado. En el teatro, en cambio, el personaje conoce límites cuantitativos derivados, en gran medida, por los lindes del espacio escénico. Si esto ocurre en el drama convencional, la obra videoescénica adquiere la capacidad representativa de la enunciación audiovisual y todo personaje es susceptible de ser representado audiovisualmente y confrontado con el personaje escénico. Por tanto, todo personaje ausente y todo personaje latente adquiere la capacidad de ser proyectado en escena. El personaje ausente, aquel que sólo es aludido por los personajes que efectivamente se encuentran en escena y que no comparte con ellos el aquí y ahora de la representación teatral (García Barrientos, 2001), podría representarse audiovisualmente como recuerdo o pensamiento de cualquier personaje escénico. Pepe El Romano, un personaje meramente aludido en La Casa de Bernarda Alba, por ejemplo, podría adquirir los rasgos de un actor concreto proyectado en la pantalla y mostrarse cómo se acerca a caballo a la casa donde lo aguarda Adela o cómo huye de la ira de Bernarda. Si en el teatro se entiende como personaje patente a aquel que estando presente es a la vez visible y que entra y sale del espacio escenográfico (García Barrientos, 2001), en la obra videoescénica también es patente el personaje que es visible a través del registro audiovisual proyectado. 


\subsection{RELACIONES DE DUPLICACIÓN, SUPERPOSICIÓN E INTEGRACIÓN}

En la obra videoescénica se alternan las configuraciones escénicas con las configuraciones videoescénicas, estas últimas tienen lugar en el caso de agrupaciones de personajes escénicos junto a personajes audiovisuales. Se pueden establecer tres tipos de relaciones básicas que vinculan al personaje escénico con el personaje audiovisual, sustentadas en el tipo de presencia aportado por la pantalla de proyección:

a) Duplicación. El personaje escénico entra en relación con su doble audiovisual registrado por una cámara y proyectado en la pantalla, produciéndose una agrupación de un solo personaje escénico, pero de dos personajes videoescénicos. Esta configuración puede ser de dos tipos en función del tiempo en el que se ha producido el registro:

- En directo, es decir, al mismo tiempo en el que se desarrolla la acción del personaje escénico, provocándose un efecto especular (imagen 3).

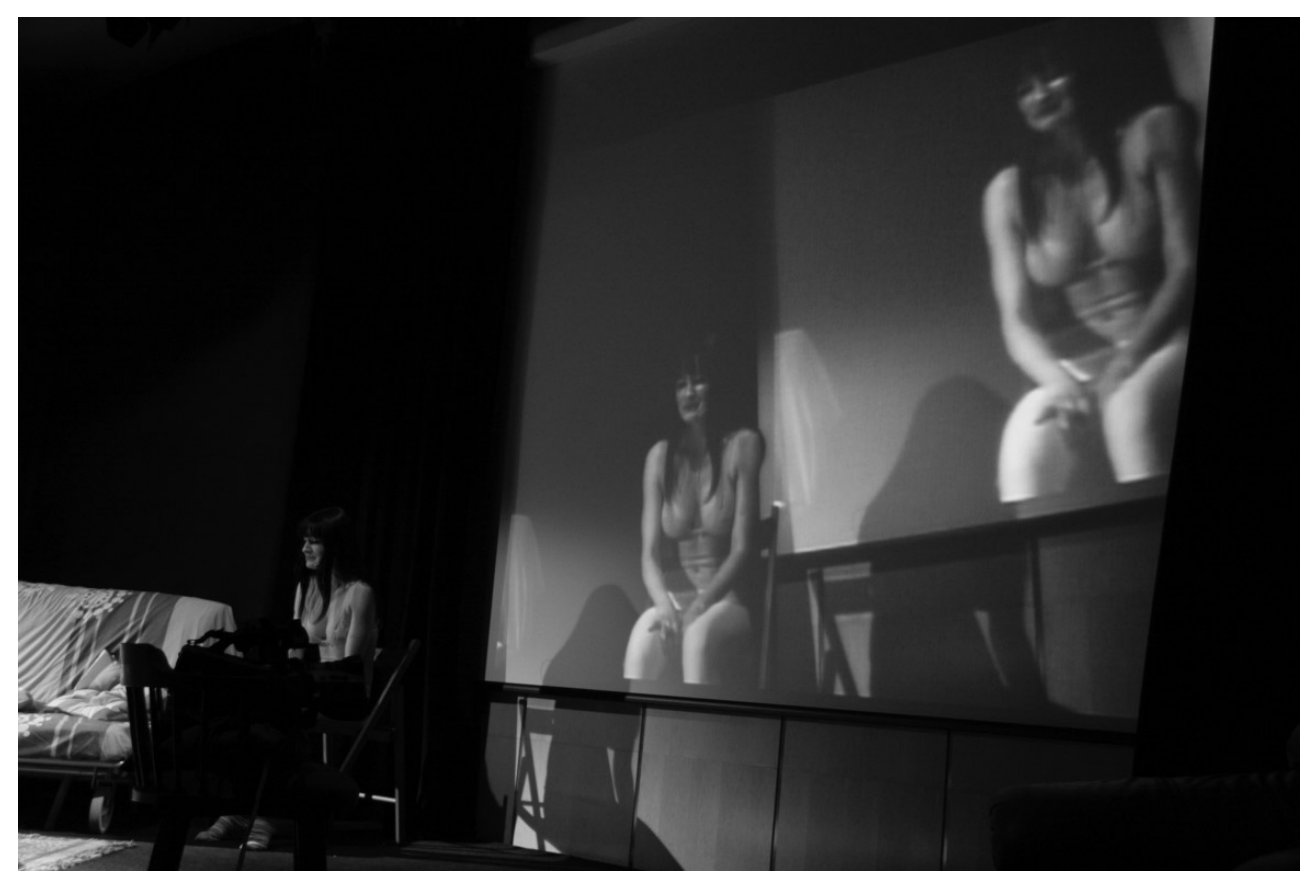

IMAGEN 3

Duplicación (en directo). Caleidoscopio de Janagah Teatro.

Museo de América, 2006.

Cortesía de la compañía 
—En diferido, si la relación se establece entre el personaje escénico y su doble registrado en otro tiempo y otro lugar. La relación que se establece es habitualmente un simulacro de diálogo que se presenta como si estuviese sucediendo en el aquí y ahora, haciendo presente el cuerpo y la verbalidad del personaje audiovisual doblado del mismo modo en el que se construye el llamado autodiálogo en el relato audiovisual (García Jiménez, 2003) que, gracias al montaje, convierte lo que sería un monólogo del personaje en una ficción dialógica.

b) Superposición. El personaje escénico entra en relación con otro u otros personajes audiovisuales que son proyectados en su presencia. La superposición implica que el foco luminoso se sitúa delante de la pantalla, es decir, se realiza mediante reflexión, con lo que no sólo el personaje escénico, sino también las sombras que genera al estar situado delante del foco luminoso, entra en contacto con los personajes audiovisuales, generando efectos expresivos que el director de escena deberá valorar (imagen 4).

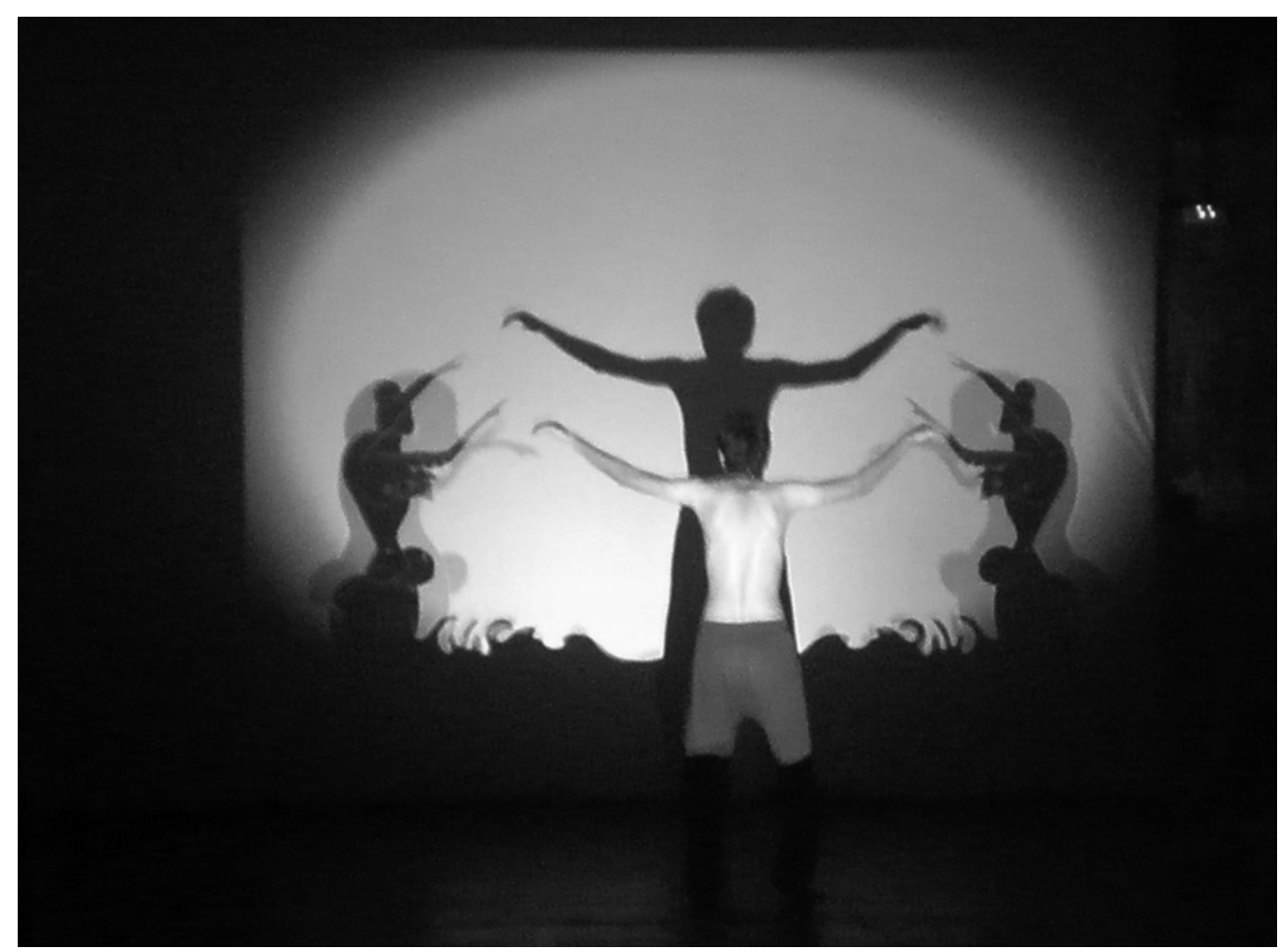

IMAGEN 4

Superposición. Nosotros, hijos de la guerra de Simbiontes.

Sala Cuarta Pared, 2011.

Cortesía de la compañía 
c) Integración. Se produce cuando el personaje escénico establece contacto con otros personajes audiovisuales registrados en otro tiempo y otro espacio de tal modo que se ha reservado un lugar concreto en la pantalla para ser ocupado por el personaje escénico. La integración está obligada a realizarse a través de retroproyección o refracción, es decir, situándose el foco luminoso tras la pantalla, puesto que de esta manera el personaje escénico no generará sombras, en este caso indeseadas, que impedirían una integración completa.

\section{La funcionalidad de la pantalla}

Por su exhaustividad, conviene tener como referencia directa el trabajo de Pablo Iglesias Simón (2008), que realiza una completa clasificación de los usos de la pantalla y la proyección de imágenes en la escena. El autor establece una serie de criterios en torno al dinamismo de las imágenes, el formato de proyección, el carácter, la procedencia, la transparencia de origen, la originalidad, la funcionalidad de las imágenes, la relación entre imagen y sonido y, finalmente, las relaciones entre el territorio del audiovisual y el conjunto de la escenificación. Sin embargo, se deben realizar algunas consideraciones, puesto que estos criterios se establecen en un mismo nivel, sin realizar ninguna distinción entre el aspecto material de la pantalla como soporte de la proyección y el contenido audiovisual proyectado. Ni entre la naturaleza de la imagen y la relación entre pantalla y los demás elementos de la escenificación. Estas categorías, convenientemente discriminadas, aportan claridad a la clasificación a la vez que la insertan en la naturaleza de los dos modos de representación que sustentan la obra videoescénica. La clasificación que aquí se realiza parte de las aportaciones de Iglesias Simón, pero se establecen en torno a una distinción básica en las tres categorías mencionadas: primero, la pantalla como soporte del universo audiovisual - lo que Metz (2002) denomina material - a través de la proyección y/o la emisión, esto es, como soporte de la forma de la expresión; segundo, la naturaleza de la imagen proyectada, esto es, la forma de la expresión audiovisual en sí misma, en la que se incluiría los criterios establecidos por Iglesias Simón en cuanto a su dinamismo, carácter, procedencia, originalidad y las relaciones entre imagen y sonido, suprimiéndose lo que el autor denomina transparencia de origen, puesto que entendemos esta categoría como redundante al recogerse su definición en la anteriormente denominada procedencia; y tercero, la vinculación entre pantalla y escena, esto es, la relación entre la forma de la expresión audiovisual y la forma de la expresión teatral o escenificación, en la que también se recogería su funcionalidad, puesto que ésta se define en cuanto a su participación en la puesta en escena en relación a los elementos teatrales convencionales. 


\subsection{LA PANTALla COMO SOPORTE DEL UNIVERSO AUDIOVISUAL}

Se establecen tres categorías, que se refieren, por un lado, a la naturaleza material del soporte; por otro, al tipo de proyección; y, finalmente, al agente generador de la imagen:

a) La naturaleza material del soporte. La proyección puede establecerse sobre elementos fisicos de distinta naturaleza material. Pueden distinguirse tres tipos:

- Soporte sólido, que puede ser: opaco, como la superficie de una pantalla convencional, el cuerpo de los personajes, como ocurre en Delirios (2007) de la compañía Simbiontes (imagen 5), o cualquier elemento escenográfico, como un mueble, una pizarra o un espejo; translúcido, como las pantallas de retroproyección o cualquier superficie construida a través de tejido semitransparente; transparente, como el cristal o determinado material plástico que se le asemeja, como se puede ver en Rojo reposado (2009), el montaje del belga Guy Cassiers en el que se proyectan imágenes sobre un enorme y grueso cristal enmarcado a la manera de algunas puestas en escena de Joseph Svoboda realizadas en los años cuarenta.

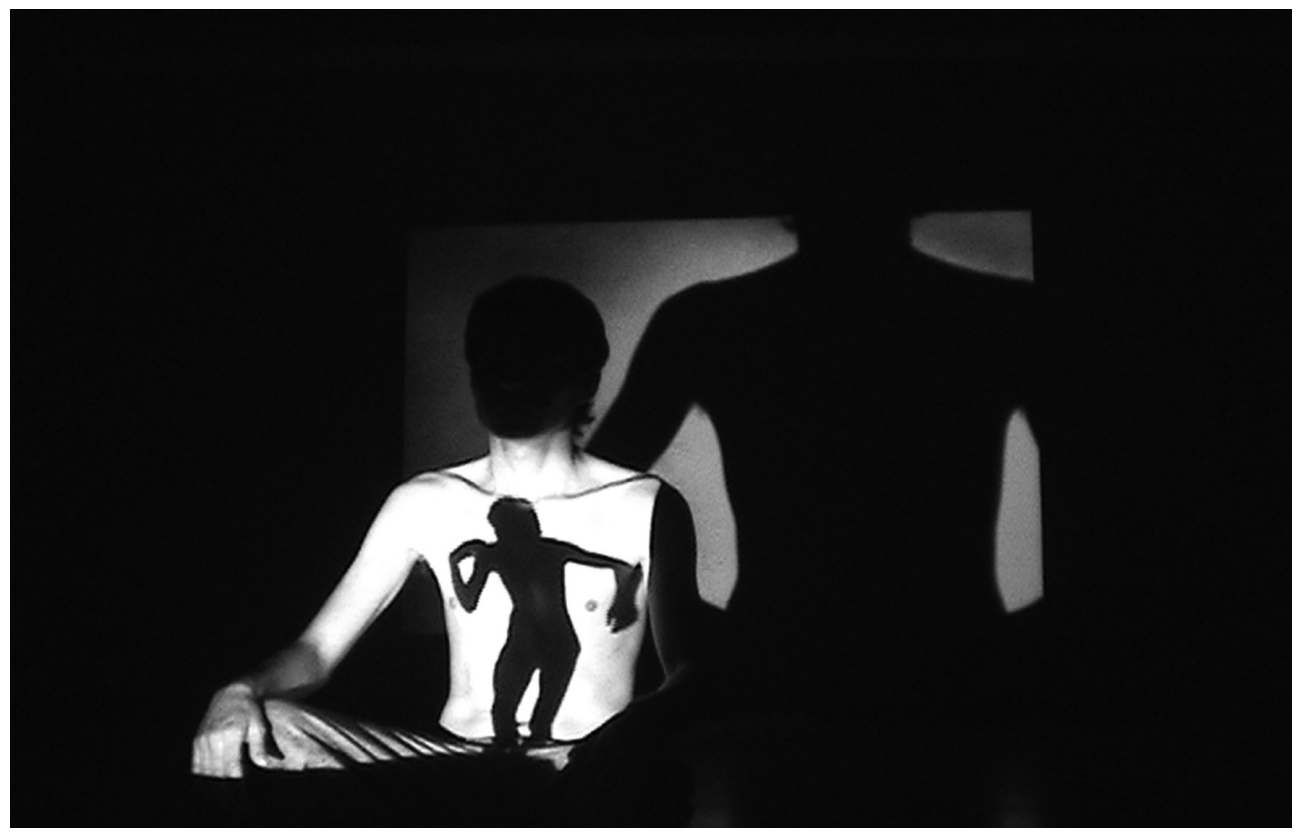

IMAGEN 5

Proyección sobre cuerpo. Delirios de la compañía Simbiontes.

Teatro Pradillo, 2007.

Cortesía de la compañía 
- Soporte líquido, como se puede ver en ciertos espectáculos de agua realizados para celebrar determinados eventos o en los conocidos espectáculos de agua de Las Vegas.

- Soporte gaseoso, como el humo generado por máquinas de humo de uso convencional en el teatro.

b) Tipos de proyección. En cuanto a la relación espacial entre el soporte, el foco luminoso y el espectador, nos encontramos ante tres posibilidades de elección: la reflexión o proyección, la refracción o retroproyección y la emisión.

— La reflexión o proyección. La imagen se construye por medio de la reflexión, entendida como el cambio de dirección que sufre un rayo luminoso cuando choca contra la superficie de un objeto. Según el ángulo en el que se produzca la proyección, nos encontraremos que ésta puede ser frontal, cenital, contracenital o lateral. Es frontal (la única a la que hace referencia Iglesias Simón) cuando el foco luminoso (el proyector) está situado en la posición que ocupa el espectador. Será cenital, cuando el foco luminoso se encuentra situado en las varas de iluminación dispuestas en el techo del escenario y la proyección se realiza en el suelo del mismo, como sucede en el montaje MacbethLadymacbeth (2008), dirigido por Carles Alfaro, donde se muestran imágenes alegóricas de la muerte en el suelo del escenario de la Naves del Matadero (Teatro Español); será contracenital —el caso opuesto-, cuando el proyector se sitúa en el suelo del escenario, proyectándose las imágenes en el techo; y será lateral, cuando se establece la situación del foco luminoso en uno de los lados del escenario.

- La refracción o retroproyección. La pantalla se sitúa entre el foco luminoso y el espectador, realizándose aquella a través de la refracción, asumida ésta como el cambio de dirección que soporta una onda de luz al pasar de un medio de irradiación a otro con una consistencia óptica diferente. A efectos concretos se entiende que la proyección se realiza desde detrás de la pantalla translúcida.

- La emisión. En este caso no existe ni reflexión ni refracción, puesto que la imagen no es proyectada, sino difundida a través de uno o varios monitores de televisión o de ordenador que ocupan un lugar en el escenario.

c) Agente generador de la imagen.

- Objeto opaco interpuesto entre el foco luminoso y la pantalla. Se realiza a través de la refracción o retroproyección y es propia del teatro de sombras

- Objeto translúcido o transparente interpuesto entre el foco luminoso y la pantalla. Se realiza a través de la reflexión o proyección. Es el caso de las 
diapositivas y la película cinematográfica utilizada en la escena a partir de los años veinte.

- Foco-imagen. Es el caso del proyector de vídeo de uso frecuente en las puestas en escena actuales, en el que el foco luminoso genera la imagen por sí mismo a partir de los parámetros que determina una imagen electrónica. No hay interposición de objeto, por tanto, sino proyección de un registro.

\subsection{LA NATURALEZA DE LA IMAGEN PROYECTADA}

En este apartado se establecen diferentes categorías que dan cuenta de las propiedades y los distintos tipos de imágenes que aparecen en la proyección audiovisual como parte de la representación teatral. Se tiene en cuenta los criterios de dinamismo, carácter, procedencia, transparencia de origen y relación entre imagen y sonido propuestos por Iglesias Simón, no así el criterio de funcionalidad, puesto que ésta, como se ha señalado, no viene determinada por la naturaleza de la imagen, sino por la relación que se efectúa entre ésta y el resto de los elementos de la representación teatral, de los que se dará cuenta en el siguiente apartado.

a) El dinamismo de la imagen. Siguiendo este criterio, nos encontramos ante dos tipos de imágenes: imagen fija e imagen en movimiento.

- Imagen fija. La proyección de una fotografia, de una pintura, de un dibujo o de una imagen electrónica estática. En el caso de la imagen fotográfica, se define, entre otros, por parámetros en relación al tamaño del plano, el ángulo, el tipo de objetivo utilizado, la profundidad de campo, la composición y la iluminación. A su vez, la imagen fija puede ser constante, cuando se presenta de una manera inalterable, o sucesiva, cuando se presentan diversas imágenes fijas en cadena.

- Imagen en movimiento. Se define, además de por las características mencionadas de la imagen fotográfica, por el montaje interno, que refleja el movimiento dentro del plano, y por el montaje externo, que da cuenta de la yuxtaposición de planos y de desplazamientos de la cámara, como la panorámica y el travelling.

b) El carácter de la imagen. Según este criterio se distinguen dos tipos de imágenes:

- Imagen de registro. Es aquella que proceden de la fotografía, en el caso de imagen fija, y de las filmaciones cinematográficas y las grabaciones videográficas, en el caso de la imagen en movimiento, en las que se recogen acciones de personajes o espacios procedentes del mundo real. 
- Imagen generada. Se trata de aquella que no reflejan un registro del mundo real - aunque pueden recrearlo o representarlo-, sino que han sido creadas a través de dispositivos informáticos. Se distinguen tres casos de imagen generada: imagen representativa, si tienen cierto carácter icónico de recreación del mundo real; imagen abstracta, si no existe ningún tipo de referencia al mundo real; imagen textual, si se proyectan textos escritos, como eslóganes, aforismos, poemas o noticias de periódicos.

c) La procedencia de la imagen. Según la imagen sea registrada o generada antes o durante la representación teatral, se establecen las siguientes categorías:

- Imagen prefijada o pregrabada inalterable. Es registrada o generada antes de la representación teatral y se muestra durante la misma. Aparece como inalterable, puesto que no se ve afectada en su constitución por la actividad producida en el escenario.

- Imagen grabada o creada en la representación. Mientras se produce la representación, una o varias cámaras reproducen, de manera simultánea o diferida, lo que sucede, de modo tal que las imágenes resultantes están absolutamente vinculadas con aquello que ocurre en la escena, reflejando detalles o puntos de vista que surgen de ella.

- Imagen autónoma emitida en el momento de la representación. La imagen no depende directamente de la representación teatral, pero se genera y se reproduce al mismo tiempo que ella, como las imágenes procedentes de cadenas de televisión, internet o videoconferencia mostradas en tiempo real.

- Imagen preprogramada interactiva. La imagen se constituye a través de la unión de imagen real y otras que se añaden a través de medios digitales, cuyos parámetros han sido previamente establecidos. El actor o el espectador podrían entonces interactuar con lo virtual a través de interfaces (un ratón o un pulsador, por ejemplo), dentro de las posibilidades programadas con antelación.

d) La originalidad de la imagen. Se distinguen dos categorías básicas: la imagen original, creada por primera vez y específicamente para su inclusión en la representación; y la imagen apropiada, que tiene una existencia anterior y diferente a la de la representación, como fotografias o material videográfico preexistente, que adquiere valor de cita o referencia documental, señalando la hibridación entre escena y audiovisual, entre realidad y representación.

e) La relación entre imagen y sonido. Las imágenes proyectadas o emitidas pueden ir acompañadas de sonido durante su difusión en la escena. Este sonido puede proceder de la voz de eventuales actores, de efectos sonoros o 
de la música. La relación que se establece entre imagen y estos tres tipos de sonido implica una serie de consecuencias que conviene establecer. Conviene destacar que desde la Narrativa Audiovisual el sonido no se entiende como un mero acompañamiento o elemento secundario, sino de un elemento primordial que se encuentra al mismo nivel que las imágenes a la hora de producir sentido, puesto que puede provocar en el espectador percepciones y reacciones diametralmente opuestas en un mismo montaje visual tan solo cambiando el sonido ligado a las imágenes, afectando, entre otras cuestiones, a la continuidad, al ritmo, a la percepción espacial o la verosimilitud de las imágenes (García Jiménez, 2003). Teniendo en cuenta lo expuesto, se establecen tres tipos de relaciones entre imagen y sonido dentro del marco de la representación:

- Relación directa. Se produce cuando el sonido confirma y afianza lo que muestran las imágenes: voz, en total sincronía y coherencia con los personajes que aparecen en la imagen; efectos sonoros, en total sincronía y coherencia con las acciones de la imagen; música, su aparición refuerza la percepción del contenido de las imágenes.

- Relación inversa. El sonido pone en cuestión lo que se presenta en imagen o aporta un sentido no incluido en ella: la voz no es atribuible a los personajes patentes, manifestando su oposición y articulando una nueva construcción del sentido; efecto sonoro, su aparición no es atribuible a ninguna de las acciones; la música promueve el contraste con las imágenes.

- Relación suplementaria. El sonido añade y destaca alguna circunstancia que subyace en la imagen: voz, las características sonoras de los personajes patentes aparecen alteradas por una causa significativa que es revelada de esta forma y también se incluye en esta categoría la aparición de un eventual narrador que comenta las acciones de los personajes o los sucesos a los que se enfrentan; efecto sonoro, devienen de las acciones y sucesos patentes o latentes en la imagen, aunque sus características sonoras se revelan alteradas por alguna causa significativa; música, se instala en la imagen como comentario de la misma, sugiriendo determinado subtexto implícito en ella.

\subsection{Relaciones entre Pantalla y ESCENA}

Este aspecto se considera fundamental en la constitución de la obra videoescénica, puesto que a través de ellas se establece la unidad de sentido de una escenificación articulada a través de elementos procedentes de los dos modos de representación sobre los que venimos reflexionando. Iglesias Simón recoge tres categorías en su marco taxonómico: relación armónica, que construye un continuo signifi- 
cativo del que forman parte por igual los elementos proyectados o emitidos y los elementos convencionales de la representación teatral; relación de oposición entre lo que presenta la imagen y lo que sucede en la escena; y relación suplementaria, aquella en que la imagen aporta información adicional. Esta clasificación es de indudable utilidad para la práctica del teatro. Sin embargo, un acercamiento científico exige una conceptualización más precisa que la inserte en la construcción teórica de una verdadera poética. Acudiendo a Metz (2002), podemos establecer una distinción entre relaciones sintagmáticas, donde se recogerían aquellas a las que Iglesias Simón denomina armónicas y suplementarias, y relaciones paradigmáticas, donde se da cuenta de aquellas que se establecen mediante oposición. Se distinguen, por tanto, las siguientes:

a) Relaciones sintagmáticas. Aquellas que proponen enunciados construidos a través de la proyección o emisión audiovisual y los elementos convencionales del teatro construyendo sintagmas, esto es, unidades de sentido compuestas por significantes audiovisuales y escénicos. Aquí quedarían comprendidas tanto las relaciones armónicas, como las relaciones suplementarias, puesto que en estas últimas las imágenes, al aportar información adicional, no hacen otra cosa que integrarse en el sintagma como elemento adyacente, adjetivo, que completa el significado de lo que sucede en la escena. En función de las acciones y sucesos reflejados en la pantalla y los reflejados en el escenario, podemos encontrarnos ante diversos casos:

- Relaciones sintagmáticas alternas. Las acciones o sucesos reflejados en la pantalla preceden o anteceden en el tiempo a lo que ocurre en el escenario.

- Relaciones sintagmáticas simultáneas. Se pueden distinguir tres tipos: las acciones que ocurren en la pantalla se producen al mismo tiempo que los que tienen lugar en el escenario, pero en distinto espacio; las acciones que ocurren en la pantalla reflejan aquello que tiene lugar en el escenario, pero desde otros puntos de vista o resaltando determinados detalles, como miradas o partes del cuerpo de los personajes (es decir, comparten tiempo y espacio); la pantalla refleja motivos o metáforas visuales de otro tiempo y otro espacio, que comentan o adjetivan lo que sucede en el escenario (imagen 6).

b) Relaciones paradigmáticas. Aquellas que dan cuenta de la oposición que se establece entre los significantes audiovisuales y los significantes teatrales convencionales, esto es, que construyen sintagmas independientes que, al formar parte del mismo proceso de enunciación, generan en el espectador efectos distanciadores que fomentan la reflexión sobre el artificio que sustenta la ficción. 


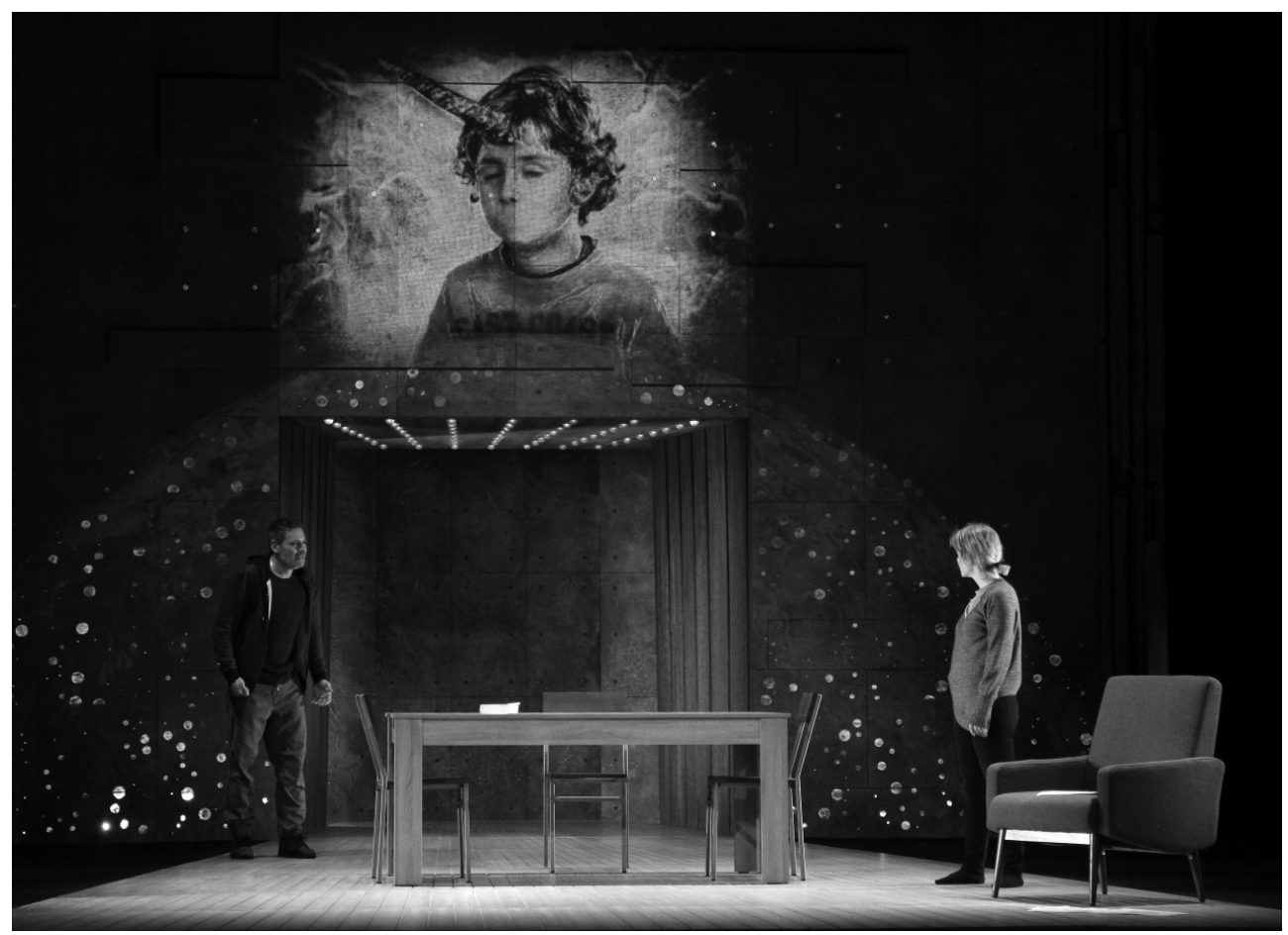

IMAGEN 6

Proyección de metáforas visuales. Pequeño Poni, dirigida por Luis Luque.

Teatro Bellas Artes, 2016.

Cortesía de Álvaro Luna

\section{Conclusiones}

La oposición fenomenológica entre personaje teatral e imagen audiovisual, entre presencia y registro proyectado, se resuelve en la obra videoescénica a través del proceso de escenificación, que vincula al actor escénico con el contenido audiovisual en la misma unidad de sentido. En ella, lo vivo y lo cosificado conviven y se relacionan, creando un mundo posible de naturaleza híbrida, ni teatral ni audiovisual, sino videoescénico. Inserto en la cultura universal de la imagen, tanto creadores como espectadores están dotados de la competencia necesaria para decodificar su espesor sígnico.

La introducción de una pantalla o cualquier otro soporte de proyección modifica el funcionamiento de los componentes fundamentales del drama. Sus características se establecen a tres niveles, esto es, como soporte de la forma de expresión 
audiovisual inserta en la forma de la expresión teatral; como forma de la expresión audiovisual en sí misma; y, sobre todo, destacando las relaciones sintagmáticas y paradigmáticas que se producen entre imágenes y escena de las que derivan su funcionalidad.

Se constata, por tanto, la importancia de la pantalla, que funciona como interfaz, en la integración del modo narrativo de enunciación audiovisual en el modo de representación dramático. El contenido audiovisual proyectado, personaje y acción, espacio y tiempo, establece relaciones específicas con los elementos convencionales de la representación teatral, estableciéndose las categorías de personaje y acción videoescénicos, espacio videoescénico y tiempo videoescénico. A través de la pantalla se produce una expansión figurativa en cuanto al personaje y la acción y una expansión del espacio y el tiempo, basado en la fragmentación y la flexibilidad de la imagen audiovisual. El mundo de la presencia y el mundo de la huella, fenomenológicamente contrapuestos, coexisten en la misma unidad de sentido gracias a ese interfaz escénico que es la pantalla.

Existe en la obra videoescénica una variación cuantitativa y cualitativa en los grados de representación del personaje que afecta, por un lado, a la visibilidad de los personajes (incluso los personajes ausentes y latentes podrían ser expuestos a la mirada del espectador) y, por otro, a las relaciones entre personaje escénico y personaje audiovisual, patentes ambos. La toma de decisiones del director de escena estará supeditada, por consiguiente, no sólo a las específicas de la puesta en escena teatral, sino también a las propias de la representación audiovisual, como la puesta en escena, la puesta en cuadro y la puesta en serie.

La introducción de la enunciación audiovisual en la representación teatral implica una variación en la manera en que es mostrado el mundo que es percibido por el personaje y, a la vez, percibido por el espectador. Esto es, una modificación de la focalización en la representación teatral, que en la obra videoescénica parece adoptar las variables del relato audiovisual. Esta cuestión no ha podido abordarse con profundidad en el presente artículo, que constata así sus limitaciones, pero abre una nueva vía de investigación centrada en el establecimiento de la focalización videoescénica que apunta a la aparición de la subjetividad del personaje a través de la ocularización y auricularización interna, en principio ajenas al modo de representación dramático.

\section{Referencias bibliográficas}

Abirached, R. (1994). La crisis del personaje en el teatro moderno. Madrid: Asociación de Directores de Escena.

Auerbach, E. (1993). Mímesis. La representación de la realidad en la literatura occidental. México DF: Fondo de Cultura Económica. 
Bazin, A. (2006). ¿Qué es el cine? Madrid: RIALP.

Benjamin, W. (1989). Discursos interrumpidos I. Madrid: Taurus.

Blas Brunel, A. E. (2006). Tecnología y gran espectáculo. ADE-Teatro Revista trimestral de la Asociación de Directores de Escena de España, 109, 54-69.

Casetti, F. y Di Chio, F. (1996). Cómo analizar un film. Barcelona: Paidós.

Diderot, D. (1995). La paradoja del comediante. Madrid: La Avispa.

Esqueda Verano, L. (2019). El cine como espejo diferido: el concepto de transferencia en André Bazin y Stanley Cavell. Palabra Clave, 22 (3), 1-27. doi: http://doi.org/ 10.5294/pacla.2019.22.3.4

Fouquet, L. (2006). Robert Lepage, l'horizon en images. Québec: Les 400 coups.

García Barrientos, J. L. (2001). Cómo se comenta una obra de teatro. Madrid: Síntesis.

García Jiménez, J. (2003). Narrativa Audiovisual. Madrid: Cátedra.

Gaudreault, A. y Jost, F. (2001). El relato cinematográfico. Barcelona: Paidós.

Iglesias Simón, P. (2008). Tentativas para una sistematización del uso del audiovisual en la puesta en escena. Acotaciones Revista de Investigación Teatral, e20, 47-82.

Melendres, J. (2005). Pantallas. ADE-Teatro Revista trimestral de la Asociación de Directores de Escena de España, 106, 64-67.

Metz, C. (2002). Ensayos sobre la significación en el cine (1964-1968), Vol. 1. Barcelona: Paidós.

Mitchell, W.J.T. (2020). ¿Qué quieren las imágenes? Vitoria: Sans Soleil.

Montes, G. (2015). Poética del drama videoescénico. La enunciación audiovisual en el teatro español. Tesis Doctoral. Universidad Complutense.

Morales Astola, R. (2003). La presencia del cine en el teatro. Sevilla: Alfar.

Naverán (de), I. (2010). Tiempo cinematográfico en la escena contemporánea. Tesis Doctoral. Universidad el País Vasco-Euskal Herriko Unibersitatea.

Pavis, P. (2002). Diccionario del teatro. Dramaturgia, estética, semiología. Barcelona: Paidós.

Paz-Gago, J. M. ${ }^{a}$ (2006). La pantalla en escena. Las tendencias tecnológicas del teatro del siglo Xxi. En J. Romera Castilla (coord..), Tendencias escénicas al inicio del siglo XXI (pp. 151-162). Madrid: Visor.

Quintana, À. (2011). Después del cine. Imagen y realidad en la era digital. Barcelona: Acantilado.

Scolari, C. A. (2004). Hacer clic. Hacia una sociosemiótica de las interacciones digitales. Barcelona: Gedisa.

Spang, K. (1991). Teoría del drama. Lectura y análisis de la obra teatral. Pamplona: Eunsa.

Thenon, L. (2005). Las dramaturgias y el desafio tecnológico. ADE-TEATRO Revista trimestral de la Asociación de Directores de Escena de España, 106, 42-48. 